\title{
Mística revolucionária: José Carlos Mariátegui e a religião
}

\author{
MICHAEL LÖWY
}

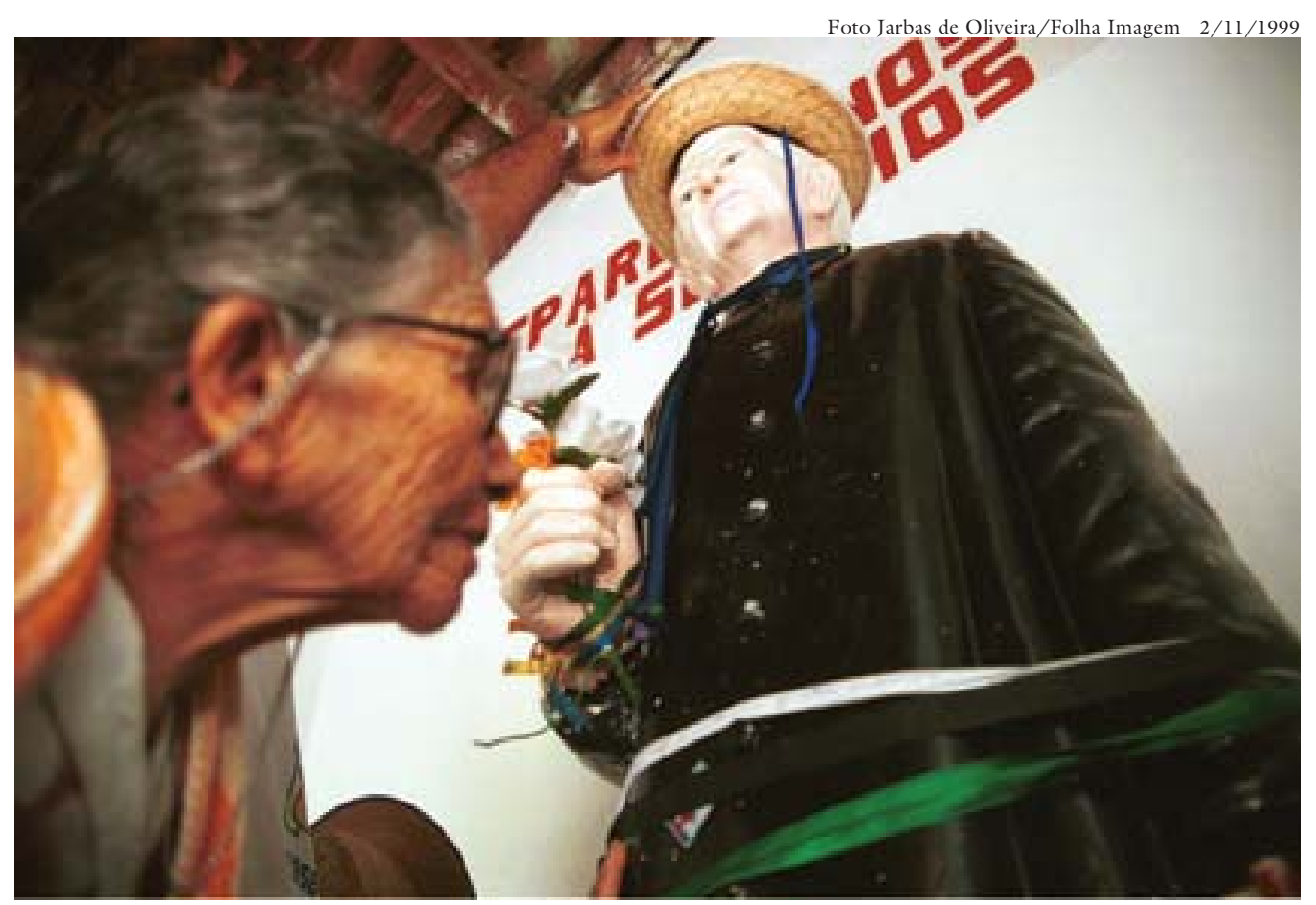

Romeira reverencia estátua do padre Cícero Romão Batista em Juazeiro do Norte (CE).

$\mathrm{N}$ ÃO SE PODE captar corretamente o pensamento de Mariátegui sobre a religião - nem sobre a filosofia, a ética, a política, a cultura ou a questão indígena - sem um conhecimento do espírito romántico/ revolucionário que inspira sua obra, nela imprimindo a sua conceituação marxista do mundo numa qualidade singular e numa força cultural visionária. Sobre a religião, e sobre outros muitos temas, Mariátegui é um heterodoxo. No âmago da sua heterodoxia marxista e na singularidade do seu discurso filosófico e político, encontra-se um momento irredutivelmente romántico.

O que é o Romantismo? Não se trata de uma escola literária e sim de um movimento cultural que nasceu no término de século XVIII como protesto contra o advento da moderna civilização capitalista, uma revolta contra a irrupção da sociedade industrial / burguesa - fundamentada na racionalidade burocrática, na reificação mercantil, na quantificação da vida social e no "desencantamento do mundo" (segundo a célebre fórmula de Max Weber). Tendo aparecido com Rousseau, William Blake e a Früromantik alemã, o Romantismo não mais desa- 
parecerá da cultura moderna e constitui, até hoje, uma das principais componentes na estruturação da nossa presente sensibilidade. A crítica romântica da modernidade capitalista é elaborada com base a valores sociais, éticos, culturais ou religiosos pré-capitalistas, configurando, em última análise, uma tentativa desesperada de "reencantamento do mundo". Pode tomar formas regressivas e reacionárias, mas também utópicas ou revolucionárias, como, por exemplo, na corrente marxista - passível de ser definida como "romântica" - de William Morris até E.P.Thompson, do jovem Lukács até Ernst Bloch, e de Walter Benjamin até Herbert Marcuse.

José Carlos Mariátegui integra-se nesta corrente numa forma original e em um contexto latino-americano, diferenciado dos da Inglaterra ou da Europa Central $^{1}$. Sua visão romântico-revolucionária do mundo, tal como formulada no famoso ensaio de 1925, "Dos concepciones de la vida" - verdadeira matriz de sua obra posterior - rejeita "a filosofia evolucionista, historicista, racionalista" portadora de "um culto supersticioso da idéia do progresso" em nome de um retorno aos mitos heróicos, ao romantismo e ao "donquixotismo" (Miguel de Unamuno). Identicamente opostas à ideologia linear e convidativa de um progresso confortável, duas correntes românticas enfrentam-se em luta mortal: $o$ romantismo de direita, fascista, desejando retornar à Idade Média, e o romantismo de esquerda, bolchevique, visando a avançar até à utopia. As "energias românticas do homem ocidental" encontraram uma expressão na Revolução Russa, que "insuflou uma alma guerreira e mistica na doutrina socialista"2.

A palavra "mística" escrita tão freqüentemente na pena de Mariátegui, é evidentemente de origem religiosa, apresentando, porém, um significado mais amplo, semelhante ao usado por Charles Péguy (autor aparentemente desconhecido por Mariátegui) ao contrapor a mística do dreyfussismo à sua degradação política. Sinaliza a dimensão espiritual e ética do socialismo, a fé no combate revolucionário, o compromisso total pela causa emancipadora, disposição heróica para arriscar a própria vida.

Para Mariátegui, a luta revolucionária - ou melhor dito, empregando o termo de Miguel de Unamuno que tanto o fascinava - a agonia revolucionária configura um re-encantamento do mundo. Mas, ao mesmo tempo em que é "mística" e "religiosa", esta luta é profana e secular: a dialética mariateguista tenta superar a oposição costumeira entre fé e ateismo, materialismo e idealismo. Num artigo sobre“"Gandhi” (1924), encontramos o seguinte raciocínio:

O socialismo e o sindicalismo, apesar de sua concepção materialista da história, são menos materialistas do que aparentam ser. Fundamentados no interesse da maioria, eles tendem a enobrecer e dignificar a vida. Os ocidentais são místicos e religiosos ao seu jeito. Por acaso a emoção revolucionaria não seria uma emoção religiosa? No Ocidente acontece que a religiosidade transferiu-se do céu para a terra. Seus motivos são humanos, são sociais; não são divinos. Pertencem à vida terrestre e não à vida celeste ${ }^{3}$. 
A temática do caráter simultanemente religioso e secular, "místico" e "terreno", do socialismo está presente em diversos escritos de Mariátegui ${ }^{4}$, sendo obviamente herética com relação à tradição marxista dominante, mas têm suas equivalências na Europa daqueles anos, em Sorel, Ernst Bloch ou mesmo no jovem Gramsci. No seu conhecido ensaio "programático" de 1925, El hombre y el mito, o pensador peruano não se opõe à Razão e à Ciência, mas insiste em que elas" não podem satisfazer toda a necessidade de infinito que existe no homem".

Rejeitando a "construção medíocre do positivismo" e a "alma desencantada" (Ortega y Gasset) da civilização burguesa, ele se apropria da "alma encantada" (Romain Rolland) dos criadores da nova civilização ${ }^{5}$. No mesmo texto encontramos uma definição original e surpreendente, portadora de exaltação romântica e de ironia polêmica contra as interpretações positivistas e cientificistas - da significação humana e espiritual do socialismo, como "alma encantada":

A burguesia entretém-se numa crítica racionalista do método, da teoria, da técnica dos revolucionários. Que incompreensão! A força dos revolucionários não reside na sua ciência e sim na sua fé, na sua paixão, na sua vontade. É uma força religiosa, mística, espiritual."É a força do Mito. A emoção revolucionária, tal como escrevi num artigo sobre Gandhi, é uma emoção religiosa $[\ldots]^{6}$

Qual é a fonte da idéia herética do marxista peruano? Do mesmo modo que muitos revolucionários europeus que buscavam quebrar o grilhão asfixiante do marxo-positivismo da Segunda Internacional, começando por Lukács, Gramsci e Walter Benjamin em 1917-1920, Mariátegui foi fascinado por Sorel, o socialista romântico por excelência (inclusive nas suas ambigüidades e regressões ideológicas) ${ }^{7}$. Em El hombre y el mito Georges Sorel mostra-se como o impulsor da hipótese duma correspondência entre religião e socialismo:

Desde faz algum tempo constata-se o caráter religioso, místico, metafísico do socialismo. Georges Sorel dizia em suas Reflexões sobre a violência: "Estabeleceu-se uma analogia entre a religião e o socialismo revolucionário na sua intenção de preparar e até reconstruir o indivíduo para uma obra gigantesca. Bergson nos ensinou, porém, que não somente a religião pode ocupar a região do eu profundo: os mitos revolucionários podem também ocupá-la". Como o mesmo Sorel nos lembra, Renan chamava a atenção sobre a fé religiosa dos socialistas, constatando sua inexpugnabilidade perante qualquer desalento ${ }^{8}$.

No entanto, ao comparar o comentário de Mariátegui com o texto de Sorel acima mencionado, vemos que nem ele nem Renan afirmam esta tese com clareza. O que Sorel escreve expressa que os mitos revolucionários ocupam no consciente o mesmo lugar que a religião ("na profundidade do eu"); a conjunção "porém" indica um equívoco na analogia proposta. Trata-se de argumento psicológico, não de paralelismo histórico ou filosófico. Segundo Sorel, Renan considera o socialismo como uma utopia, significando uma "explicação superficial" da obstinação dos socialistas. A palavra "religião" não consta neste contexto9. De fato, a idéia do "caráter religioso, místico, metafísico" do socialismo não é formulada diretamente nem por Sorel, nem por Renan e sim pelo próprio Mariátegui! 
Em alguns dos seus escritos, Engels apresenta uma comparação entre o início do cristianismo e o socialismo moderno. Mas a comparação do autor do Anti-Dühring aponta uma analogia histórica entre dois movimentos de massa perseguidos pelas autoridades, mais do que uma afinidade substancial entre socialismo e religião. $\mathrm{O}$ autor marxista mais próximo das conceituações do pensador peruano foi provavelmente o jovem Gramsci, que, num artigo sobre Charles Péguy (1916), rende homenagem ao "sentimento místico religioso do socialismo... que tudo invade e nos leva muito além das polemicas ordinárias e miseráveis dos pequenos políticos vulgarmente materialistas"10.

Afora as Reflexiones sobre la violencia de Sorel, La agonia del cristianismo de Miguel de Unamuno é a outra grande referência de Mariátegui para seu debate sobre as afinidades entre o político e o religioso. Em sua resenha do livro em 1926, propõe uma interpretação do marxismo como uma espiritualidade agônica, no sentido que o filósofo espanhol dá a esta palavra:

Eu percebo - escreve Unamuno - ao mesmo tempo a política elevada ao nível da religião e a religião elevada ao nível da política. Com idêntica paixão falam e sentem os marxistas, os revolucionários. Aqueles em quem o marxismo é espírito, é verbo. Aqueles em quem o marxismo é luta, é agonia.

Partindo deste raciocínio, Mariátegui desenvolve uma surpreendente comparação entre Marx e Dostoiévski: tal como o escritor russo, o fundador do socialismo moderno seria "um cristão, uma alma agônica, um espírito polêmico"; em outras palavras - e citando agora Vasconcelos -, "o atormentado Marx encontra-se mais perto de Cristo que o doutor de Aquino" 1 . O argumento é pouco convencional, mas se insere de algum modo na tradição marxista - que se estende de Engels a Kautsky e até Rosa Luxemburgo - tratando de interpretar Cristo e o cristianismo primitivo como precursores do moderno socialismo. Obviamente, Mariátegui vai além disso: não lhe interessa tanto a filiação histórica quanto a afinidade espiritual entre Cristo e Marx, almas agônicas ${ }^{12}$.

De fato, bem além de Marx, o tema romântico, "quixotesco", da agonia está relacionado com a própria identidade político-religiosa do socialista peruano, seu Sitz-im-Leben, sua visão pessoal sobre o compromisso revolucionário:

No meu caminhar encontrei uma fé. Isto explica tudo. Cabe esclarecer que a encontrei por minha alma ter saído de madrugada na procura de Deus. Como diria Unamuno, sou uma alma agônica (agonia, no sentido como ele com tanta razão acentua, não significa morte, significa luta). Agoniza quem combate ${ }^{13}$.

Em outras referências a Unamuno durante aqueles anos, volta o tema da dialética entre religião e política, com o interesse de Mariátegui focalizando principalmente a primeira parte da afirmação do pensador hispânico, a elevação espiritual da política, em oposição ao seu miserável rebaixamento administrativo:

Se, para Huidobro, a política é exclusivamente a do Palais Bourbon, sem dúvida poderíamos outorgar aos seus artifícios toda a autonomia pretendida. Acontece que a política, para os que a sentimos elevada na categoria de uma religião, 
como diz Unamuno, é própria trama da História. Nas épocas clássicas, ou de plenitude de uma ordenação, a política pode ser somente administrativa e parlamentar: nas épocas românticas ou de crise da ordem, a política ocupa o primeiro plano da vida.

Assim o proclamam, com sua conduta, Louis Aragon, André Breton e seus camaradas da Revolução supra-realista - os melhores espíritos da vanguarda francesa - marchando para o comunismo ${ }^{14}$.

A referência ao surrealismo - movimento de revolução espiritual que fascinava Mariátegui a ponto de lhe dedicar diversos artigos - é interessante na medida em que consistiu numa corrente romântica à procura de um reencantamento do mundo, porém em oposição total à religião cristã tradicional. Até que ponto isto estaria contradizendo a imagem de Cristo e a citação de Unamuno? O que o mais atrai em Unamuno e nos surrealistas vem a ser a alma encantada, a "mística", a agonia: o arriscado combate pelo valores supremos, a pesquisa heróica de sentido. Isto é, alguma coisa muito diferente da religião institucional, com seus dogmas e seu clero.

Este aspecto institucional encontra-se, ao contrário no centro da atenção no capítulo "El factor religioso" dos Siete ensayos de interpretación de la realidad peruana

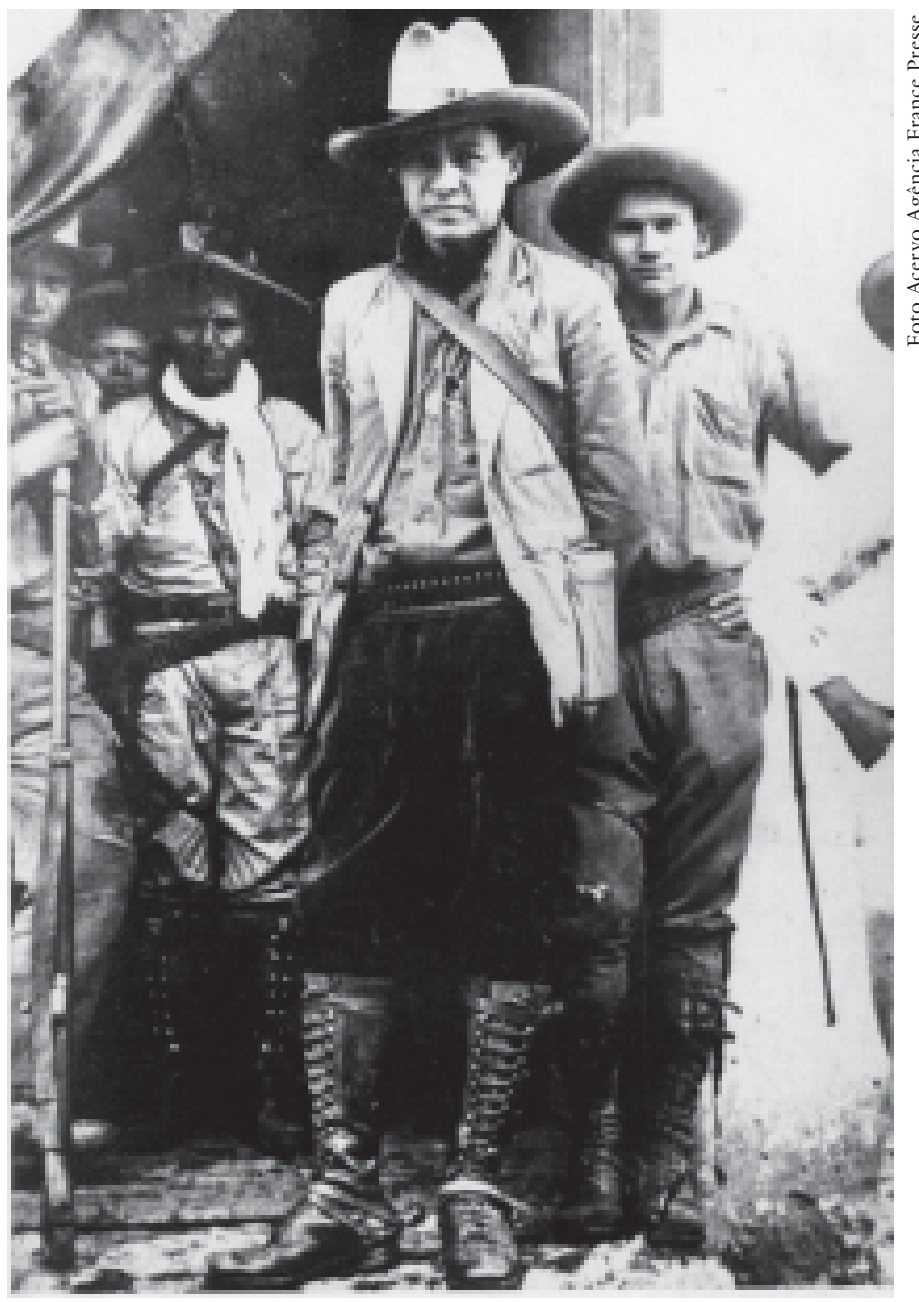

O lider revolucionário nicaraguense Augusto Cesar Sandino. No movimento sandinista predominaram os socialistas cristãos. (1929): nele, Mariátegui se afasta das reflexões místicas dos ensaios publicados nos anos 1924-1926, passando a estudar a religião do ponto de vista científicosocial, isto é, histórico, sociológico ou antropológico. Mesmo assim, na introdução do capítulo, o marxista peruano preocupa-se em evitar toda conceituação reducionista dos fenômenos religiosos, distanciando-se de uma crítica liberal ou iluminista sobre o "obscurantismo clerical": 
Foram superados definitivamente os tempos de apriorismo anticlerical [...]. O conceito de religião cresceu em extensão e em profundidade. A religião não é reduzida mais a uma igreja e a um ritual. São reconhecidos nas instituições e nos sentimentos religiosos significados muito diferentes dos que ingenuamente eram atribuídos, com radicalismo incandescente, por pessoas que identificavam religiosidade e obscurantismo.

A crítica revolucionária não mais regateia nem contesta às religiões, as igrejas, seus serviços à humanidade, ou seu lugar na história ${ }^{15}$.

A primeira parte do capítulo é dedicada à "La religión del Tawantinsuyo", isto é, à civilização incaica pré-colombiana. Como observa corretamente Antonio Melis em recente comentário, o principal acerto do autor foi à contraposição estabelecida entre a religião oficial inca e a religião popular. A primeira é um instrumento de poder, vinculado às instituições do estado andino; a segunda, portadora de tonalidade animista, tem raízes culturais mais profundas ${ }^{16}$. O "coletivismo teocrático" dos incas tinha, de acordo com Mariátegui, finalidades temporais mais do que espirituais, e desaparece com a destruição do Estado inca. Isto não acontece com a religião popular dos antigos peruanos, a qual consegue sobreviver à conquista e à colonização. Utilizando os conceitos antropológicos desenvolvidos por James Frazer em sua obra clássica La rama dorada, Mariátegui a define como uma forma de animismo, fundamentada na magia dos totens e dos tabus, "elementos instintivos de uma religiosidade primitiva ${ }^{17}$.

A análise de Mariátegui é sugestiva, causando, porém a impressão de usar um esquema conceitual que não lhe permite captar a riqueza do imaginário religioso andino. De fato, ele já tinha sinalizado os limites de uma tentativa de interpretação "científica" nesta linha de pensamento, num ensaio em 1925, que parece ser uma crítica antecipada ao capitulo de 1928:

Se Valcárcel fosse um racionalista e um positivista [...] nos falaria [...] de "animismo" e de "totemismo" indígenas [...], mas então Valcárcel provavelmente não teria escrito Los hombres de piedra. Nem teria sinalizado, com religiosa convicção, o franciscanismo do quéchua como sendo um dos rasgos essenciais do sentimento indígena. E, portanto, sua versão do espírito do Tawantinsuyo não seria total.

Mas a ciência mata a lenda, destrói o símbolo. Ao passo que a classificação científica do mito dos "homens de pedra" como um simples caso de animismo não nos ajuda a melhor entender o Tawantinsuyo, a sua lenda ou a poesia nos apresentam seu sentimento cósmico filtrado neste símbolo ${ }^{18}$.

A segunda parte do capítulo trata de "A Conquista Católica", isto é, da "parte ativa, direta, militante" que teve a Igreja na conquista hispânica e no estabelecimento, no espaço do antigo poder inca, de uma "nova teocracia". Analisando o catolicismo colonial instalado durante séculos na região andina, Mariátegui o caracteriza como sistema burocrático e parasitário, no qual "o componente religioso ficou absorvido e dominado pelo elemento eclesiástico". Ao mesmo tempo, porém, reconhece o papel positivo exercido por amplos setores do clero na defesa dos direitos dos indígenas: 
Os índios, explorados nas minas, nas construções e nas "encomendas" encontraram nos conventos e também nas paróquias seus defensores mais dedicados. O padre de Las Casas, em quem floreciam as melhores virtudes missionárias do evangelizador, teve precursores e continuadores ${ }^{19}$.

A parte mais original desta seção é a comparação entre protestantismo e catolicismo, entre a colonização anglo-saxônica da América do Norte e a hispânica da América do Sul. Citando Engels, Mariátegui observa que a reforma de Calvino atendia às necessidades da burguesia mais avançada da época. Sua interpretação, porém, vai além disso: na sua opinião "o protestantismo surge na história com a levedura espiritual do processo capitalista"; ou, em outras palavras, "a reforma forjou as armas morais da revolução burguesa, abrindo o caminho ao capitalismo". Esta hipótese se aproxima mais dos trabalhos de sociologia religiosa de Max Weber do que dos escritos de Marx e Engels. Ao falar sobre a "consangüinidade dos dois grandes fenômenos" - capitalismo e protestantismo - Mariátegui utiliza o mesmo termo que aparece em La ética protestante y el espiritu del capitalismo de Weber: Wahlverwandtschaft, o parentesco eletivo. Porém, nos Siete ensayos não encontramos nenhuma referência a Weber ou suas teses. Localiza-se somente uma citação no escritor espanhol Ramiro de Maeztu: no calvinismo a salvação é conhecida pelo cumprimento dos deveres de cada homem no seus próprios afazeres, "o que implica a moralização da maneira de gastar o dinheiro" 20 .

Mariátegui compartilha com Gramsci seu interesse pelo protestantismo, considerando se tratar de uma forma moderna e dinâmica da religião, não acreditando num seu possível desenvolvimento na área latino-americana, onde sua expansão é prejudicada pelo movimento anti-imperialista que considera as missões protestantes como avançadas tácitas do capitalismo anglo-saxão: britânico e norte-americano ${ }^{21}$.

A terceira parte do capítulo, "La Independencia y la Iglesia", examina como a falta de ruptura com o passado colonial transformou o Estado peruano independente num Estado semi-feudal e católico, onde "a subsistência dos privilégios feudais logicamente acompanhava a dos privilégios eclesiásticos". Mariátegui também critica a ineficácia da corrente radical ou “gonzalez-pradista”, cuja agitação anticlerical não conseguiu resultados por carecer de um adequado programa econômico-social ${ }^{22}$.

Nas últimas páginas do capítulo sobre "El factor religioso", Mariátegui tira duas conclusões gerais tentando resumir, na sua opinião, o ponto de vista marxista sobre a religião. A primeira se apóia no materialismo histórico para rejeitar, novamente, o anticlericalismo liberal:

O socialismo, segundo as conclusões do materialismo histórico - que convém não confundir com as conclusões do materialismo filosófico - considera que as formas eclesiásticas e as doutrinas religiosas são peculiares e inerentes ao regime econômico-social que as sustenta e produz. E, portanto, se preocupa em mudar este e não aquelas. A simples agitação anticlerical é considerada pelo socialismo como um diversivo liberal burguêes ${ }^{23}$. 
A segunda reafirma a tese soreliana dos seus artigos dos anos 1925-1926, agora, porém numa linguagem mais de acordo com a orientação psicológica freudiana? - do socialista francês.

Como foi anunciado por Sorel, a experiência histórica dos últimos lustros comprovou que os atuais mitos revolucionários ou sociais podem ocupar a consciência profunda dos homens com a mesma plenitude dos antigos mitos religiosos ${ }^{24}$.

Evidentemente, o conceito ligado à palavra religião em Mariátegui apresenta-se com um significado bem mais amplo do que o tradicionalmente usado. Um trecho dedicado a Gonzalez Prada na seção "El Processo de la Literatura" dos Siete ensayos o afirma explicitamente:

Gonzalez Prada se iludia [...] ao nos pregar anti-religiosidade. Hoje conhecemos muito mais do que na sua época sobre a religião [...]. Sabemos que uma revolução é sempre religiosa. A palavra religião tem um novo valor, um novo sentido. Serve para designar alguma coisa além de um rito ou uma igreja. Não importa que os soviéticos escrevam nos seus panfletos propagandisticos que "a religião é o ópio dos povos". O comunismo é essencialmente religioso. O que ainda motiva equívocos é a velha acepção do termo ${ }^{25}$.

Mariátegui não propõe uma nova definição de religião, superando "a velha acepção", e explicando seu "novo significado". Pode-se inferir que está sendo introduzida uma nova conceituação ético-política e espiritual, em decorrência da "necessidade de infinito que existe no homem" por ele mencionada em $1925 \mathrm{e}$ da procura de um mito heróico que possa dar um sentido e "encanto" à vida.

No seu importante último escrito En defensa del Marxismo (1928-1929), encontramos novamente a temática soreliana comparando mitos revolucionários e mitos religiosos. O ponto de vista de Mariátegui sobre o tema é diferente dos de outros marxistas "bergsonianos" e "sorelianos" nos anos 1917-1923 (Lukács, Gramsci, Bloch e Benjamin). Estes, no curso dos anos de 1920, e à medida que se aproximam do movimento comunista oficial, vão se afastar de qualquer referência a Sorel. O marxista peruano é o único que, a pesar de sua adesão à Terceira Internacional, continua incorporando temas do autor de Reflexões sobre a violência:

Superando as bases racionalistas e positivistas do socialismo da sua época, Sorel encontra, em Bergson e nos pragmatistas, idéias que revigoram o pensamento socialista, restituindo-o à missão revolucionária dos seus inícios e da qual tinha sido gradualmente afastado pelo aburguesamento intelectual e espiritual dos partidos e seus elementos parlamentares, os quais, no campo filosófico, ficavam satisfeitos com o historicismo mais vulgar e um evolucionismo mais medroso. A teoria dos mitos revolucionários, que aplica ao movimento socialista a experiência dos movimentos religiosos, estabelece as bases de uma filosofia da revolução $[\ldots]^{26}$

Contrariamente a Lukács ou Gramsci, o comunista Mariátegui continua insistindo no "ascendente religioso do marxismo", assim como na vocação "idealista/ religiosa" do materialismo socialista: "O materialista, se professa e serve 


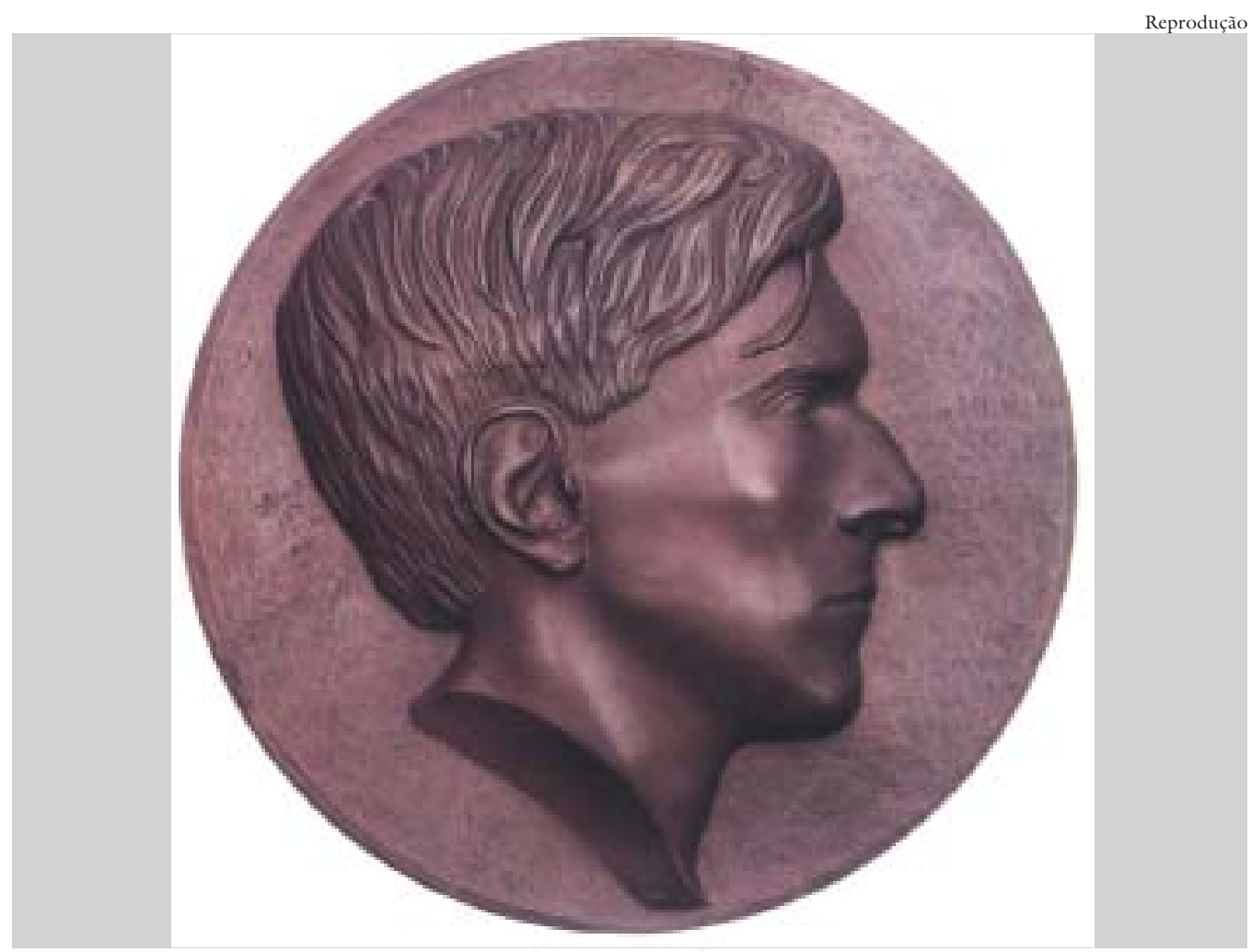

Medalhão de bronze com o perfil de José Carlos Mariátegui, obra de Lina Zapata Agurto.

sua fé religiosamente, somente pode ser colocado como oposto e diferenciado do idealista por uma convenção de linguagem ${ }^{27}$. A surpreendente dialética entre materialismo e idealismo - este último identificado à ética e à religião - é um dos temas mais originais do marxista peruano; em outro texto "programático", o famoso editorial "Aniversário e Balanço" da revista Amauta (1928) é apresentado numa formulação deliberadamente paradoxal e provocadora:

O materialismo socialista enfeixa todas as possibilidades de ascensão espiritual, ética e filosófica. E nunca nos sentimos mais ardorosa e religiosamente idealistas que quando a idéia assenta seus pés sobre a matéria ${ }^{28}$.

A interpretação positivista da doutrina socialista é incapaz de dar conta de seu profundo significado moral e político - afirmação válida para uma grande parte do marxismo oficial da Segunda e da Terceira Internacional (em vias de estalinização em 1928): "Vã é a tentativa da sua catalogação como simples teoria científica enquanto opera na história como evangelho e método de um movimento de massas" 29 . Partindo do pressuposto fundamental de que "cada ato do marxismo comporta um acento de fé e vontade, de convicção heróica e criadora", Mariátegui propõe, em vários trechos de sua Defesa do Marxismo, uma comparação éticopolítica entre a mística dos revolucionários e a dos cristãos: entre as assembléias da III Internacional e o misticismo da cristandade das catacumbas (analogia apontada por Engels, que Mariátegui não cita), entre Rosa Luxemburgo e Teresa de Ávila ${ }^{30}$, e, de modo geral, entre os heróis do socialismo e os da religião. 
As biografias de Marx, de Sorel, de Lenin, de inumeráveis diversos agonistas do socialismo, não têm por que invejar a beleza moral e a plena afirmação espiritual das biografias dos heróis e ascetas que, em tempos passados, agiram segundo uma concepção espiritualista ou religiosa de acordo com a acepção clássica destas palavras ${ }^{31}$.

Concluindo: além de suas interessantes observações socio-históricas sobre "o fator religioso" no Peru, a contribuição mais original e inovadora de Mariátegui à reflexão marxista sobre a religião é sua hipótese relativa à dimensão religiosa do socialismo, sua análise das afinidades eletivas (utilizando o termo weberiano) entre mística revolucionária e fé cristã. Certamente, não se trata de uma formulação sistemática, mas de um conjunto de fragmentos carregados de brilhantes intuições ${ }^{32}$.

Provavelmente não é simples coincidência que o sacerdote peruano Gustavo Gutierrez, fundador da teologia da libertação, ministrou na Universidade de Lima um curso "completamente dedicado às idéias de Mariátegui" e que sua obra fundamental Teologia de la Liberación - Perspectivas (1971) contêm varias referências ao autor dos Siete ensayos ${ }^{33}$.

De fato, as hipóteses de Mariátegui são uma contribuição substancial para entender Camilo Torres, a teologia da libertação e a participação dos cristãos nos movimentos revolucionários da América Latina - como o sandinismo nicaraguense assim como a "mística revolucionária" de movimentos político-sociais como o MST brasileiro ou o EZLN de Chiapas ${ }^{34}$.

\section{Notas}

1 Nestor Kohan coloca Mariátegui na corrente do anti-imperialismo culturalista, de orientação socialista e antipositivista, inspirada pela obra romântica de José Enrique Rodó, Ariel (1900); participam nesta "irmandade de Ariel”, além da amauta peruana, o cubano Julio Antonio Mella, o salvadorenho Farabundo Marti, o argentino Deodoro Roca e vários outros mais. N. Kohan, "Os combates de Mariátegui”, De Ingenieros al Che. Ensayos sobre el marxismo argentino y latino-americano, Buenos Aires, Biblos, 2000, pp. 97-98.

2 J. C. Mariátegui, "Dos concepciones de la vida”, 1925, El alma matinal, Lima, Amauta, 1971, pp. 13-16.

3 J. C. Mariátegui, “Gandhi”, 1924, La escena contemporanea, Lima, Amauta, 1964, p. 198.

4 Existem poucos trabalhos sobre o tema da religião e Mariátegui. Foram de grande utilidade as páginas sobre "Ética e religiosidade" do livro de Alfonso Ibañez, Mariátegui, revolución y utopia, Lima, Tarea, 1978, pp. 74-78.

5 J. C. Mariátegui, El hombre y el mito, 1925, El alma matinal, p. 22. Romain Rolland é uma referência importante para Mariátegui, pela dimensão religiosa e humanista da sua“"alma encantada”: "O espírito de Romain Rolland é fundamentalmente religioso. 
[...] Não é seu pensamento político - ele ignora e despreza a política - o que poderia nos atrair: é sua grande alma. [...] É sua fé humana. É a religiosidade da sua ação e do seu pensamento". ("Romain Rolland", 1926, em El alma matinal p. 135).

6 J. C. Mariátegui, El alma matinal, p. 22. O parágrafo seguinte repete a última frase do artigo citado sobre Gandhi: "Os motivos religiosos se deslocaram do céu para a terra. Não são divinos: são humanos, são sociáveis”.

7 A melhor análise sobre a influência de Sorel em Mariátegui é o de Robert Paris, em seus ensaios já "clássicos", "El marxismo de Mariátegui" e "Mariátegui, un 'sorelismo' ambíguo", em José Aricó (org.) Mariátegui y los orígenes del marxismo latino-americano, México, Siglo XXI, 1978.

8 J. C. Mariátegui, El alma matinal, p. 22.

9 G. Sorel, Reflexions sur la violence, 1908, Paris, Seuil, 1990, p. 32.

10 Antonio Gramsci, "Charles Péguy ed Ernesto Psichari”, 1916, Scritti Giovanili, p.3334. Provavelmente, Mariátegui não conhecia este trabalho do jovem Gramsci. As afinidades entre Mariátegui e Gramsci podem ser esclarecidas pela leitura do capítulo "Gramsci e Mariátegui" no livro de Francis Guibal y Alfonso Ibañez, Mariátegui Hoy, Lima, Tarea, 1987, pp. 133-145.

11 “'La agonia del cristianismo' de Don Miguel de Unamuno”, 2/1/1926, Signos y obras, Lima, Amauta, 1975, p. 120.

12 Aparentemente, Mariátegui conseguiu convencer Miguel de Unamuno, porquanto em carta endereçada ao pensador peruano, o autor da Agonia do Cristianismo reconhece que "Marx não é um professor: ele é um profeta" (carta citada por Mariátegui em Defensa del Marxismo, 1928-1929, Lima, Amauta, 1976, p. 56).

13 "Una encuesta a José Carlos Mariátegui", 23/7/1926, La novela y la vida, Lima, Amauta, 1976, p. 154.

14 “Arte, Revolución y Decadencia”, nov. 1926, El artista y su epoca, Lima, Amauta, 1973 , p. 20.

15 J. C. Mariátegui, Siete ensayos de interpretación de la realidad peruana (1928), Lima, Amauta, 1976, p. 162.

16 A. Melis, José Carlos Mariátegui hacia el Siglo XXI. Prólogo de "Mariategui Total", separata, 1994, p.15.

17. J. C. Mariátegui, Siete ensayos... pp. 164-167. Sobre a influência de Frazer em Mariátegui, ver de Antonio Melis, "Presencia de James George Frazer en la obra de Mariátegui”, em Mariátegui y las ciencias sociales, Lima, Biblioteca Amauta, 1982.

18 J. C. Mariátegui, "El rostro y el alma del Twantinsuyu”, 11/9/1925, Peruanicemos al Peru, Lima, Amauta, 1975, p. 64.

19 J. C. Mariátegui, Siete ensayos... pp. 170-172.

20 J. C. Mariátegui, 7 Ensayos, pp. 177-180. Seria interessante verificar se no artigo de Maeztu mencionado por Mariátegui - "Rodó y el Poder", Repertorio Americano, tomo VII, nº 6, 1926 - existe alguma referência direta a Max Weber.

21 J. C. Mariátegui, Siete ensayos... p. 192. A antevisão de Mariátegui foi válida para a primeira metade do século. No entanto, nos últimos vinte anos tem se desenvolvido espectacularmente a variante pentecostal do protestantismo, apesar do sentimento anti-imperialista. 
22 Idem, pp. 185-191.

23 Idem, p. 192.

24 Idem, p. 193.

25 J. C. Mariátegui, Siete ensayos... pp. 263-264.

26 J. C. Mariátegui, Defensa del Marxismo (1928-1929), Lima, Amauta, 1976, p. 22

27 Idem, pp. 59-60.

28 J. C. Mariátegui, ““Aniversario y Balance” (1928), Ideologia y politica, Lima, Amauta, 1971, p. 250.

29 Idem, p. 41

30 "Tempos virão em que [Rosa de Luxemburgo], a assombrosa mulher que escreveu na prisão cartas maravilhosas a Luisa Kautsky, despertará uma devoção idêntica e um reconhecimento semelhante ao de Teresa de Àvila" (Defensa del Marxismo p. 44).

31 J. C. Mariátegui, Defensa del Marxismo, p. 103.

32 Uma comparação entre idéias análogas - muito diversas, porém nas suas implicações de Ernst Bloch, Walter Benjamin ou Lucien Goldmann, excede os limites do presente ensaio.

33 Ver a entrevista de G.Gutierrez com Luis Peirano, Quehacer, mar. 1980, p. 115. No entanto, em momento algum Gutiérrez cita de forma direta os trechos da obra de Mariátegui referentes ao "ascendente religioso do marxismo".

34 Tentei estudar estes movimentos e as raízes sócio-religiosas do "cristianismo da liberação", no meu livro La guerra de los dioses. Religión y Política en América Latina, Mexico, Siglo XXI, 2000.

Michael Löwy estudou Ciências Sociais na Universidade de São Paulo (USP) e doutorou-se na Sorbonne sob orientação de Lucien Goldmann. Vive em Paris desde 1969 e é autor de vários livros, dentre eles, La théorie de la révolution chez le jeune Marx (Maspero); Método dialético e teoria politica (Paz e Terra); Para uma sociologia dos intelectuais revolucionários (Ciências Humanas); Ideologias e ciência social (Cortez); As aventuras de Karl Marx contra o barão de Münchbausen (Busca Vida). @ - lowym@free.fr

Tradução de Leopold Rodés. O original em espanhol - "Mistica revolucionaria: José Carlos Mariátegui y la religion" - encontra-se à disposição do leitor no IEA/USP para eventual consulta.

Recebido em 20.11.04 e aceito em 12.2.05. 